\title{
The Mediating Role of Medical Students' Attitudes towards Distance Education in the Relationship between E-Learning Styles and Academic
} Achievements

\author{
Melih Dikmen (Corresponding author) \\ Department of Educational Sciences, Firat University, Turkey \\ Tel: 90-424-237-0000Ｅ-mail: melihdikmen@gmail.com
}

Received: September 30, 2020 Accepted: November 5, 2020

Published: November 17, 2020

doi:10.5296/jei.v6i2.17789 URL: https://doi.org/10.5296/jei.v6i2.17789

\begin{abstract}
The COVID-19 global outbreak is a growing concern for continuing medical education. The COVID-19 pandemic has led many medical education programs to be carried out online in the world. This research aims to examine the mediating effect of attitudes towards distance education in explaining the relationship between e-learning styles and academic achievements of students in medical education conducted online. The research was carried out on 148 students studying in a six-year medical program at a university. In the research, students completed the e-learning styles scale, attitude scale towards distance education, and online questionnaire include some demographic information via Moodle-based Learning Management System (LMS). In addition, end of year grade point averages of the students was also used within the scope of the research. In the research, the direct effect of e-learning styles on the grade point average and an indirect effect on attitude towards distance education were tested with the mediation model. It was determined that gender is not a significant variable on e-learning styles and attitudes towards distance education. It was observed that students with higher daily internet usage times had higher attitudes towards distance education. In the research, it was observed that the attitude towards distance education has a mediating effect on the relationship between e-learning style and academic success. It is important to consider e-learning styles and attitudes towards distance education to increase academic success in online medical courses and provide better learning outcomes.
\end{abstract}

Keywords: Medical education, E-learning styles, Attitude towards distance education, Academic achievement, Online learning 


\section{Introduction}

It is known that the global epidemic of COVID-19 negatively affects many sectors. These unprecedented adverse effects have interrupted the health system of many countries around the world (Hall et al., 2020). One of the reasons for these failures in the system is the lack of sufficient health personnel during the pandemic process. The fact that there are some problems in continuing education in the medical faculties that train health personnel in this process made this situation more complicated. Although the problems in higher education programs in the COVID-19 epidemic and even the interruption of education are considered reasonable, it is important to make health education sustainable. Due to the global epidemic, we are in the need to train future doctors have never been this much focus (Rose, 2020). In previous pandemics, such as Severe Acute Respiratory Syndrome (SARS), there was a temporary interruption in education and training services. During the SARS outbreak, there have been disruptions in education and training in China and Canada. China has decided to discontinue formal education (Ahmed, Allaf, \& Elghazaly, 2020). The COVID-19 outbreak appears to have similar disruptions. However, in addition to hoping that these failures with COVID-19 are temporary, the possibility that the epidemic may occur again in the autumn period is obscuring the process (Sherbino \& Atzema 2004). Due to the restrictions on maintaining physical distance all over the world, ways to adapt quickly to different education and training methods have been sought to eliminate the problems in education (Alvin et al., 2020; Nassar et al., 2020). Since medical education is practice-oriented, it has been tried to find solutions for how to do education in faculties (Rose, 2020; Ahmed, Allaf, \& Elghazaly, 2020). Many medical students worldwide are trained in physical settings for problem-solving or discussions in small groups during the first 12 to 18 months of teaching. In the final stages of the teaching process, they have experience by participating in activities such as advanced clinical rotations and academic projects (Rose, 2020). In this regard, it can be said that the teaching activities to be conducted for medical faculties differ from other programs.

In Turkey, as in many countries in the world, it has been decided to provide education and training in medical schools by distance education (Dikmen \& Bahçeci, 2020). Teaching activities to be carried out in this process can significantly change the way education and training of future doctors (Rose, 2020). For this reason, it is important to make some arrangements and improvements to increase the quality of education and training activities in online learning environments. Determining students' online learning styles can be seen as an important variable to provide rich and quality educational content to students who are alone in online environments (Gülbahar \& Alper, 2014). In cases where the student is aware of his/her characteristics and understands his/her experiences, he/she will adapt more easily to the learning activities carried out with the teaching process (Gülbahar \& Alper, 2014). Research in the literature (Felder \& Henriques, 1995; John, Shahzadi, \& Iqbal-Khan, 2016; Elban, 2018) highlights the positive relationship between learning styles and academic achievement. Also, Whiteley (2007) emphasizes that technology can enable the preparation of content suitable for different learning styles since it produces a wide variety of options day by day. Research in the literature (Fahy \& Ally, 2005; Offir, Bezalel, \& Barth, 2007) states that designing the electronic course contents produced for online environments according to the 
learning styles preferred by students will increase academic achievement. Similarly, Hamada, Rashad, and Darwesh (2011) states that personalized teaching approaches are important to students' motivation and academic achievement. Kia, Aliapour, and Ghaderi (2009) observed that students in social, auditory, verbal, and individual learning styles in e-learning environments are more successful than students with logical and physical styles. According to Beadles and Lowery (2007), the learning styles of students who prefer the traditional learning environment and e-learning environment are different from each other. It is stated that these differences may arise from many variables. For example, in online environments, students are expected to have some software and hardware skills and to be a little competent in using technology. In traditional environments, variables such as classroom communication, self-control, internal and external motivation are considered important in terms of learning. In terms of all these differences, it is stated that (Dikmen, 2020) learning styles can be seen as important in solving at least some of the questions about determining in which environment students can learn better.

The rapid transition to distance education in the course of the COVID-19 global epidemic brought along some problems. Distance education tools give students a different feeling of the learning experience. In this process, negative feelings or technical problems that may occur in students can make it difficult for the student to focus, participate, and motivate the learning activities. Apart from designing and configuring an online course appropriately, there are a variety of tools that can be used to promote student engagement and interaction in online learning environments. In addition to all these, one of the variables that facilitate the effectiveness of distance education is the attitude of students (Junior et al., 2018). The concept of attitude means "aptus" in Latin, meaning "ready for action" (Arkonaç, 2005). Tuncer and Bahadir (2017) regard the attitude as an important psychological variable for the individual to perform a behavior with its cognitive, affective, and behavioral dimensions. The positive attitudes of students towards distance education will make the content conveyed more meaningful. Attitudes make the behavior easier; therefore, increasing positive attitudes will increase the commitment of the student to academic development (Junior et al., 2018). While the positive attitudes of the individual increase the achievement in the learning process, it is stated that negative attitudes can cause failure (Kazazoğlu, 2013). According to Falowo (2007), the prejudices that occur due to technical problems, insufficiency of materials, and communication disruption in the online environment cause individuals to have a negative perspective towards distance education. It is reported that this situation negatively affects students' learning and academic achievement. Researchers conducted (Erdogan, Bayram, Deniz, 2008; Konting, 1990) show that the individual's attitude towards the course of learning is an important variable in terms of academic achievement.

In this study, it was aimed to test the structural equation model for the relationship between the e-learning styles of medical faculty students and grade point average (GPA) in the COVID-19 process. In addition, the mediating role of the attitude towards distance education in the relationship between e-learning styles and GPA will be examined. The model for the purpose of the research is presented in Figure 1. 


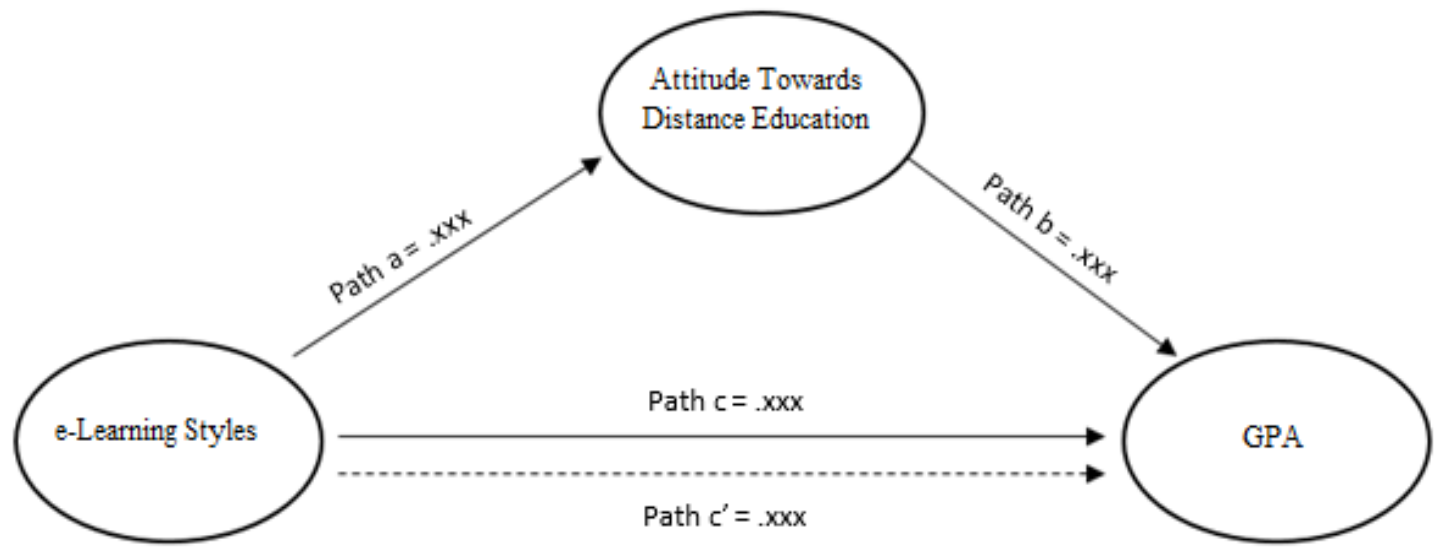

Figure 1. The hypothetical structural equation model depicting the direct impact of medical students' e-learning styles on the GPA and the indirect (mediation) effect through attitude towards distance education

When the literature is analyzed, it is seen that there are more than seventy learning style models (Coffield, Moseley, Hall, \& Ecclestone, 2004). It can be said that many of these models are taken into consideration in classroom environments where traditional education is carried out. With the COVID 19 epidemic, interruption of formal education worldwide has brought to mind the availability of learning styles online. Whiteley (2007) states that online teaching technologies can offer various possibilities for different learning styles. Chen (2019), Li, Yin, Zhang, and David (2019) emphasize that students' learning styles can be important for academic achievement in online learning environments. Besides all these situations, while Uzuntiryaki, Bilgin, and Geban (2003) stated that learning style has a strong effect on academic achievement, Atalay and Ay (2016) stated that learning style is not a significant variable on academic achievement. Due to the uncertainties and contradictory findings in the literature, the findings of this research can be seen as important in determining the relationship between e-learning styles and academic achievement. Also, in the literature, e-learning styles in terms of medical education will be discussed for the first time with this research. The e-learning styles scale to be used in the research was developed by Gülbahar and Alper (2014) by making use of the Kolb (1976), Felder and Soloman (1991), Felder and Silverman (1988) and Grasha-Reichmann learning style scales. The scale consists of seven different learning styles. These are called Audio-visual Learning, Verbal Learning, Active Learning, Social Learning, Independent Learning, Logical Learning, and Intuitive Learning. Students in the Audio-visual Learning style prefer learning materials such as images, paintings and cartoons, and vocalized electronic books in online environments. The students in the Verbal Learning style have a wide vocabulary. These students think that they learn best by reading. They enjoy working with learning materials consisting of written documents (Word, pdf, etc.) in online environments. Students in the Active Learning style prefer learning by playing games and simulations. These students enjoy exploring and researching as well as thinking that they learn by doing best by experiencing. Students in the Social Learning style like to participate in interactive group activities. They care about the interaction with the instructor and other students in online environments. These students prefer to participate in 
simultaneous activities such as chat, virtual classroom, and whiteboard application. Students in the Independent Learning style enjoy working on their own. These students prefer different time activities such as forums, blogs, and wikis in online environments. Students in the Logical Learning style learn best by thinking in detail. They enjoy solving puzzles and playing logic games, and also their problem-solving skills are high. They are realistic, and if they understand the parts, they also understand the whole. Students in the Intuitive Learning style think that they learn best by associating them with their feelings. They prefer random processes to hierarchical processes; therefore, it is important to offer different resources and options in online environments (Gülbahar \& Alper, 2014).

In the literature, no studies investigating the relationship between the e-learning styles of students in online courses and GPA during the COVID-19 process. In this context, findings from the research may contribute to the literature in terms of medical education. In addition to these situations, it is thought that the research can make a unique contribution to the literature in terms of examining the mediating role of the attitude towards distance education in the relationship between e-learning styles and grade point average. In line with the general purpose of the research, the e-learning styles of medical faculty students and their attitudes towards distance education were compared in terms of some independent variables. One of these variables is the gender of the students. The perspective on gender and the value provisions in this subject differ from time to time and from society to society. Therefore, it is seen that the effect of the gender variable is constantly investigated when an action is evaluated in scientific studies (Dikmen \& Çağlar, 2015). Accordingly, the question "Do the e-learning styles and attitudes towards distance education differ statistically among the medical students according to their gender?" was being examined as a sub-problem in the research. Another independent variable considered in the scope of the research is the daily internet usage times of medical students. Experience affects the individual's opinion on whether he/she can achieve any job at the desired level (Bandura, 1992). Therefore, the daily internet usage times of medical school students may affect their online experience, e-learning styles, and their attitudes towards distance education. Accordingly, the question "Do the e-learning styles and attitudes towards distance education of medical students differ statistically according to the daily internet usage times? was among the sub-problems of the research. In addition, in the research, it will be tried to determine for which purpose the medical students use the internet the most.

\section{Method}

The research was carried out according to the relational screening model, which is one of the quantitative research models. In this context, the mediation role of medical students' attitudes towards distance education in the relationship between e-learning styles and grade point average was examined. The research was carried out on 148 students studying in a six-year medical program at a university. During the COVID-19 outbreak period (for 12 weeks), all courses at the medical school were taught exclusively through distance education using the Moodle-based Learning Management System (LMS). The students with different learning styles were divided into different groups in the learning management system. Teaching materials were prepared according to the dominant e-learning styles of all students and 
uploaded to the LMS. Students were invited to fill out the measurement tools used in the research online via the LMS. The scales were left open for last five weeks of the academic year. Two reminders were sent to students via LMS to complete and send the scales only once. End of year exams were conducted online through the LMS. The score that medical students obtained from the end of year exams constitute the grade average point. For this reason, the academic success of the students was based on the GPA of the period they were in.

\subsection{Ethical Approval}

This research received ethical approval from the University Research Ethics Board. All participants provided written informed consent, before participating in the research.

\subsection{Measures}

As the data collection tool, the e-Learning Styles Scale developed by Gülbahar and Alper (2014), the Distance Education Attitude Scale developed by Ağır, Gür, and Okçu (2007) and grade point scores obtained from LMS were used. The e-Learning Styles scale consists of 37 items (e.g., I like to participate in simultaneous activities (chat, virtual classroom, whiteboard application, etc.) while learning) and seven dimensions. Each dimension represents different e-learning styles. These are entitled as Audio-visual Learning, Verbal Learning, Active Learning, Social Learning, Independent Learning, Logical Learning, and Intuitive Learning. According to the responses of the participants, the dimension with the highest average score among 7 different e-learning styles is accepted as the dominant e-learning style. A five-point Likert-type grading, 'Almost always', 'Often', 'Occasionally', 'Rarely' and 'Almost never', was used to obtain responses to each item on the scale of e-Learning styles. Gülbahar and Alper (2014) stated that while developing the e-learning styles scale, they created the item pool by using Kolb (1976), Felder and Soloman (1991), Felder and Silverman (1988) and Grasha-Reichmann learning style scales. In the reliability research conducted by Gülbahar and Alper (2014), the Cronbach alpha internal consistency coefficient for the entire scale was calculated as .94 . When the reliability coefficients related to the dimensions of the scale were examined, it was determined as Independent Learning .82, Social Learning .87, Audiovisual Learning .86, Active Learning .83, Verbal Learning .86, Logical Learning .77 and Intuitive Learning .72. In this research, the Cronbach alpha internal consistency coefficient calculated for the whole scale was calculated as .81. In terms of the dimensions of the e-learning styles scale, it was determined that Cronbach Alpha value ranged from .77 to .82. Accordingly, it can be said that the scale is a reliable scale for use in research.

Another data collection tool used within the scope of the research is the Attitude Scale towards Distance Education. The scale consists of two dimensions and a total of 21 items. The dimensions of the scale are called "advantages of distance education" and "limitations of distance education". The items in the scale were developed from (1) (Strongly disagree) to (5) (Strongly agree) as a five-point Likert type. Ağır, Gür, and Okçu (2007) stated that the Cronbach alpha coefficient that they calculated to determine the reliability of the scale is .84 . In this research, the Cronbach alpha coefficient on the attitude scale towards distance education was determined as .96 and it was deemed appropriate to be used in the research. 
Another data collection tool used in the study is the grade point average (GPA) of medical students in the related semester. Students' GPA was the result of the exam held at the end of the year. The questions regarding the exam held at the end of the year were prepared by a commission of 6 faculty members. This exam, which makes up the GPA, was conducted online over the Learning Management System (LMS). The exam consists of a hundred questions. In terms of exam safety, the location and the options of the questions were presented to the student mixed. Also, it was not possible to return to a question that was passed, and one minute was given to the student to answer each question. The average scores of exam range from zero to one hundred. The average difficulty of the items used in the exam was at "medium level".

\subsection{Participants}

Research was conducted at a university in Turkey, Faculty of Medicine students. 148 first and second-year medical students participated in the research. The reason for the inclusion of the first and second-grade students in the research is that all the practical and theoretical courses are taught over LMS and exams are conducted online. $76(51.4 \%)$ of the students are women and $72(48.6 \%)$ are men. The ages of students vary between 18 and 24 .

\subsection{Statistical Analysis}

SPSS 21 (Statistical Package for Social Sciences) for our basic statistical analyzes and AMOS 21 (trial version) programs for mediation analysis were used. Before starting data analysis, it was checked whether there is invalid or missing data. Then the data were evaluated for normal distribution and linearity. Tabachnick and Fidell (2007) stated that the skewness and kurtosis values between [-1.5 and 1.5] can be accepted as an indicator of the normality of the distribution. When the kurtosis and skewness values of the scales were examined, it was seen that the normality assumption coincided with each other. Besides, the correlation levels of the variables used in the research were examined and it was evaluated whether there were multiple connections. The multiple connections was examined with Variance inflation factor (VIF) and it was determined that there were no multiple connections between the variables (acceptable VIF < 5.0). Descriptive statistical methods (number, percentage, average, standard deviation) were used in the analysis of the data. A Chi-square test was used to compare categorical variables. Independent Sample t-test was used in binary comparisons (Levene $\mathrm{p}>.05$ ) in terms of independent variables. In comparing independent variables containing more than two groups in terms of dependent variables, homogeneity was first tested by the Levene test. As a result of the determination of Levene $(p<.05)$, Kruskall Wallis $\mathrm{H}$ analysis, one of the non-parametric tests, was used.

Some index values were calculated and interpreted for the structural equation modeling of the research. Moosbrugger and Müller (2003) RMSEA value of 0.05 and below is a good fit, values between 0.08 and 0.1 are an acceptable fit; If GFI, AGFI, CFI and IFI values are close to 1 , it indicates a good fit. In the interpretation of the effect sizes in the structural equation modeling, Cohen's (1992) (.10 low, .30 medium, .50 and above strong) ranges were taken into account. 


\section{MIMacrothink}

\section{Results}

When the most preferred e-learning styles of medical students are examined, it was determined in the order, logical learning $(n=48)$, independent learning $(n=42)$, audio-visual learning $(n=30)$, social learning $(n=15)$, active learning $(n=6)$, intuitive learning $(n=6)$ and verbal Learning $(n=1)$ (Table 1$)$.

Table 1. Distribution of e-learning styles of students participated in the research

\begin{tabular}{|l|l|l|}
\hline E-learning style & $\mathbf{N}$ & $\mathbf{\%}$ \\
\hline Audio-visual Learning & 30 & 20.3 \\
\hline Verbal Learning & 1 & 0.7 \\
\hline Active Learning & 6 & 4.1 \\
\hline Social-Learning & 15 & 10.1 \\
\hline Independent Learning & 42 & 28,4 \\
\hline Logical Learning & 48 & 32.4 \\
\hline Intuitive Learning & 6 & 4.1 \\
\hline Total & 148 & 100.0 \\
\hline
\end{tabular}

Another situation examined in the research was the distribution of e-learning styles of medical students according to their gender and whether their e-learning styles differed statistically significantly or not. It was determined that the e-learning styles of medical students did not differ significantly according to their gender $\left(X^{2}=11.01, p=.088\right)$. Accordingly, it can be said that gender is not a significant variable in terms of e-learning styles $\left(X^{2}=11.01 ; p=.088\right)$. When the distribution of e-learning styles according to the gender of medical students is examined, it is seen that male students prefer; 15 Audio-visual Learning, 1 Verbal Learning, 4 Active Learning, 11 Social Learning, 15 Independent Learning, 25 Logical Learning, and 1 Intuitive Learning style. Female students, on the other hand, prefer 15 Audio-Visual Learning, 4 Active Learning, 11 Social Learning, 27 Independent Learning, 23 Logical Learning, and 1 Intuitive Learning style (Figure 2). 


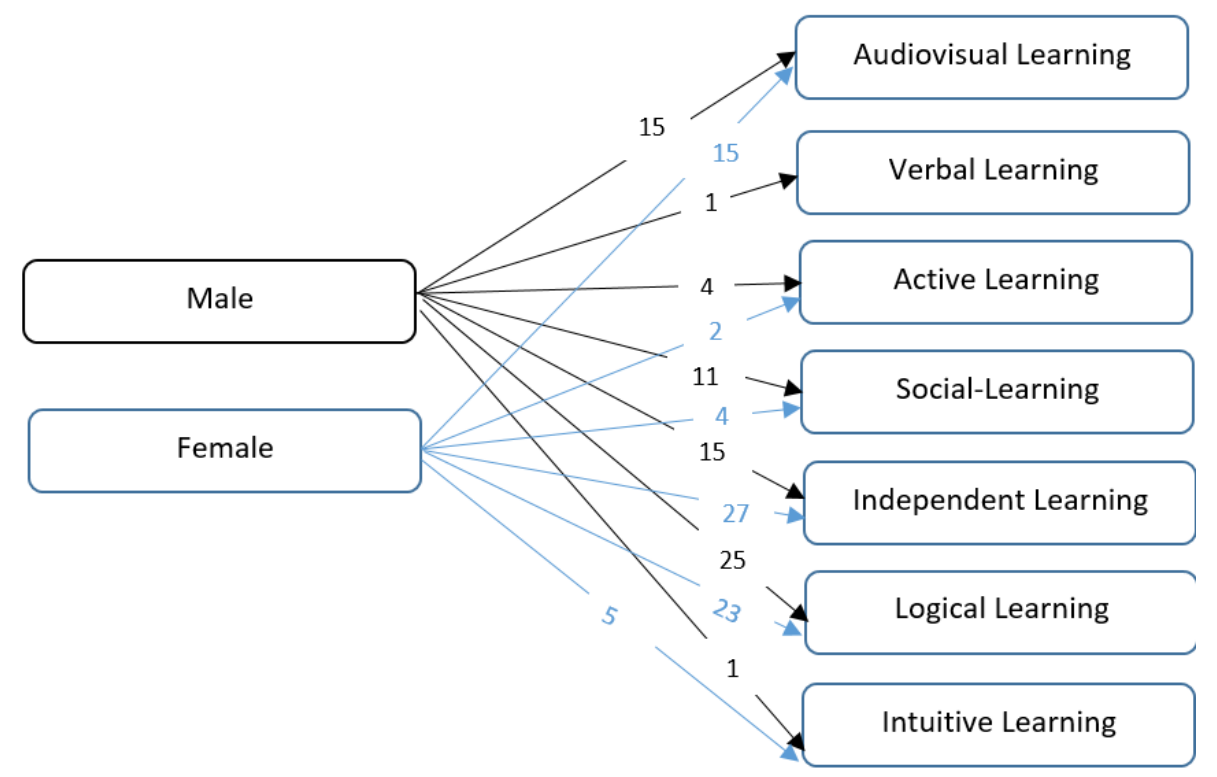

Figure 2. Distribution of e-learning styles of medical students by gender

In the research, the distribution of e-learning styles according to daily internet usage times of students, which is another independent variable, was examined. It is seen that the learning styles of students with less than 1 hour of daily internet usage vary like 4 Audio-Visual Learning, 2 Social Learning, 2 Independent Learning, 8 Logical Learning and 3 Intuitive Learning. Students with 1-3 hours of daily internet usage vary like 11 Audio-visual Learning, 3 Active Learning, 3 Social Learning, 16 Independent Learning, 20 Logical Learning, and 1 Intuitive Learning. Students with 4-7 hours of daily internet usage vary like 9 Audio-Visual Learning, 3 Active Learning, 6 Social Learning, 18 Independent Learning, 15 Logical Learning, and 2 Intuitive Learning. It is seen that students whose daily internet usage time is more than 7 hours adopt 6 Audio-Visual Learning, 1 Verbal Learning, 4 Social Learning, 6 Independent Learning, and 5 Logical Learning. It was determined that the distribution of e-learning styles did not differ significantly according to students' daily internet usage time $\left(X^{2}=24.02 ; \mathrm{p}>.05\right)$. Accordingly, it can be said that daily internet usage time is not a significant variable in the e-learning style (Figure 3 ). 


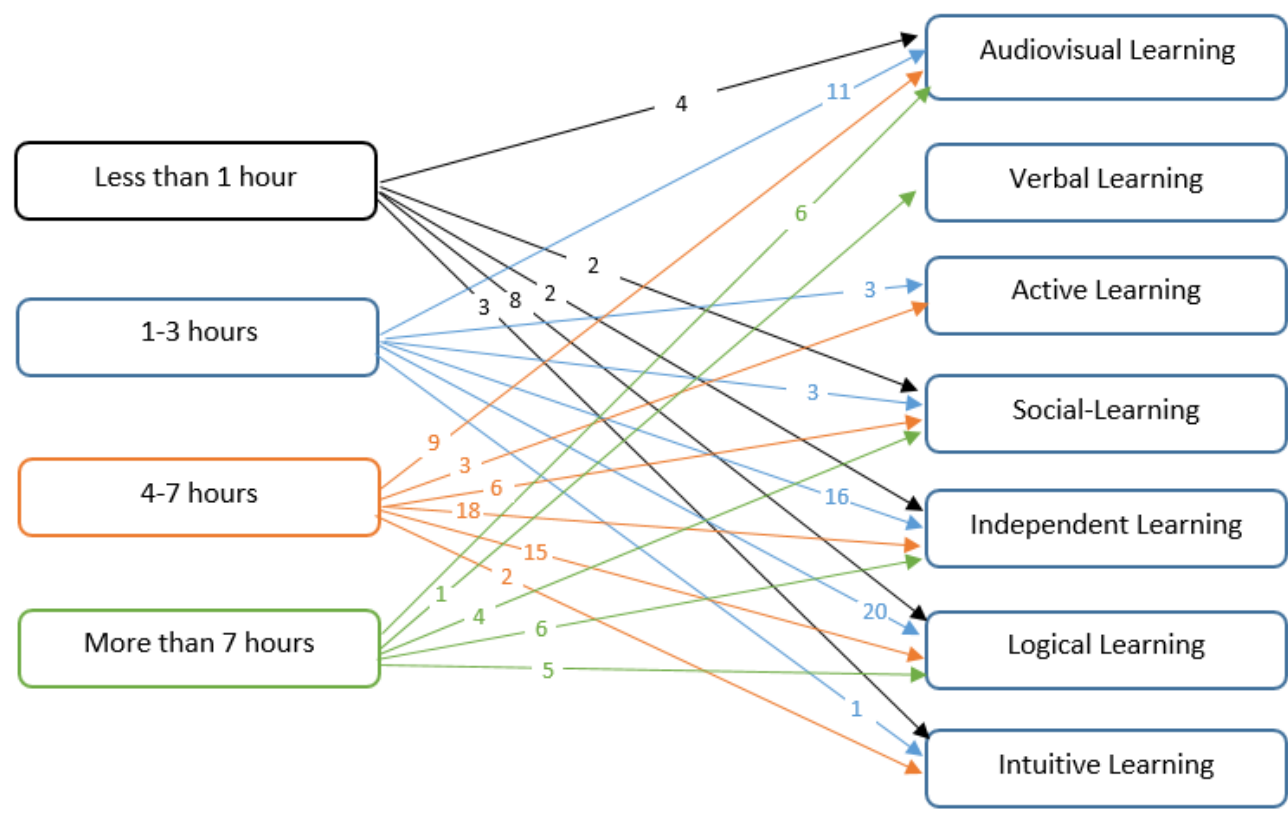

Figure 3. Distribution of e-learning styles of medical students according to daily internet usage times

Another situation examined within the scope of the research is the attitudes of medical students towards distance education according to their gender. Analysis results for this situation are given in Table 2.

Table 2. Comparison of students' attitudes towards distance education by gender

\begin{tabular}{|c|c|c|c|c|c|c|c|}
\hline \multirow{2}{*}{ Scales } & \multirow{2}{*}{ Gender } & \multirow{2}{*}{$N$} & \multirow{2}{*}{ M } & \multirow{2}{*}{ SD } & \multicolumn{3}{|c|}{ t-test } \\
\hline & & & & & $t$ & df & p \\
\hline \multirow{2}{*}{ ASDE } & Female & 76 & 2.52 & 0.91 & \multirow{2}{*}{-1.493} & \multirow{2}{*}{146} & \multirow{2}{*}{.138} \\
\hline & Male & 72 & 2.76 & 0.99 & & & \\
\hline \multirow{2}{*}{$\mathrm{ADE}$} & Female & 76 & 2.67 & 0.97 & \multirow{2}{*}{-1.898} & \multirow{2}{*}{146} & \multirow{2}{*}{.60} \\
\hline & Male & 72 & 2.98 & 1.06 & & & \\
\hline \multirow{2}{*}{ LDE } & Female & 76 & 2.23 & 0.89 & \multirow{2}{*}{-.416} & \multirow{2}{*}{146} & \multirow{2}{*}{.678} \\
\hline & Male & 72 & 2.30 & 1.05 & & & \\
\hline
\end{tabular}

Note. ASDE $=$ Attitude Scale for Distance Education (Overall); ADE = Advantages of Distance Education Subscale, LDE = Limitations of Distance Education Subscale.

As seen in Table 2, it was determined that the attitude scale and sub-dimensions of medical students did not differ significantly according to their gender $(p>.05)$. In this context, it can 
be said that gender is not a significant variable in terms of attitude towards distance education.

Another independent variable discussed in the research, the attitudes of students towards distance education in terms of daily internet usage times were investigated. Russell and Purcell (2009) state that parametric tests should not be used with groups under 30 . When the distribution of the groups related to the daily internet usage of the students was examined, it was observed that the frequency numbers were below 30. For this reason, Kruskal Wallis $\mathrm{H}$ analysis, which is a nonparametric test, was used. The results of the KWH test are given in Table 3.

Table 3. Comparison of students' attitudes towards distance education according to daily internet usage times

\begin{tabular}{|c|c|c|c|c|c|c|c|}
\hline Scales & Groups & $N$ & M.R. & $x^{2}$ & $s d$ & $p$ & Difference \\
\hline \multirow{4}{*}{ ASDE } & Less than 1 hour & 19 & 33.03 & \multirow{4}{*}{21.68} & \multirow{4}{*}{3} & \multirow{4}{*}{.000} & \multirow{4}{*}{$\begin{array}{l}1<2 \\
1<3 \\
1<4\end{array}$} \\
\hline & 1-3 hours & 54 & 84.08 & & & & \\
\hline & 4-7 hours & 53 & 80.69 & & & & \\
\hline & More than 7 hours & 22 & 71.89 & & & & \\
\hline \multirow{4}{*}{$\mathrm{ADE}$} & Less than 1 hour & 19 & 31.24 & \multirow{4}{*}{22.92} & \multirow{4}{*}{3} & \multirow{4}{*}{.000} & \multirow{4}{*}{$\begin{array}{l}1<2 \\
1<3 \\
1<4\end{array}$} \\
\hline & 1-3 hours & 54 & 84.19 & & & & \\
\hline & 4-7 hours & 53 & 79.67 & & & & \\
\hline & More than 7 hours & 22 & 75.61 & & & & \\
\hline \multirow{4}{*}{ LDE } & Less than 1 hour & 19 & 43.95 & \multirow{4}{*}{12.91} & \multirow{4}{*}{3} & \multirow{4}{*}{.005} & \multirow{4}{*}{$\begin{array}{l}1<2 \\
1<3\end{array}$} \\
\hline & $1-3$ hours & 54 & 80.31 & & & & \\
\hline & 4-7 hours & 53 & 82.20 & & & & \\
\hline & More than 7 hours & 22 & 68.07 & & & & \\
\hline
\end{tabular}

Note. ASDE = Attitude Scale for Distance Education (Overall); ADE = Advantages of Distance Education Subscale; LDE = Limitations of Distance Education Subscale; 1 = Less than 1 hour, $2=1-3$ hours, $3=4-7$ hours, $4=$ More than 7 hours.

As can be seen in Table 3, when the KWH results are examined, it has been determined that as the duration of daily internet use increases, the attitude towards distance education increases $(p<.05)$.

Averages, standard deviations, and correlation levels for all variables used in the research are shown in Table 4. It was determined that there was a significant positive relationship between 


\section{Macrothink}

the independent variables (ASDE and ELS) and the dependent variable in the model ( $p$ $<.01)$.

Table 4. Descriptive statistics and Pearson correlation coefficients regarding the variables of the research

\begin{tabular}{|l|l|l|l|l|l|l|}
\hline Variables & $\mathbf{M}$ & SD & Skewness & Kurtosis & $\mathbf{1}$ & $\mathbf{2}$ \\
\hline 1: ASDE & 2.65 & .078 & .147 & -.653 & - & \\
\hline 2: ELS & 3.49 & .031 & -.182 & .249 & $.330^{* *}$ & \\
\hline 3: GPA & 80.78 & 1.07 & -.607 & -.507 & $.394^{* *}$ & $.258^{* *}$ \\
\hline
\end{tabular}

Note. $\mathrm{ASDE}=$ Attitude Scale for Distance Education; ELS = E-learning Styles; GPA = Grade Point Average. 1 =ASDE, $2=\mathrm{ELS}, 3=\mathrm{GPA}, \mathrm{N}=148$.

$* * \mathrm{p}<.01$.

In the research, a structural model was created for the relationship between e-learning styles and the grade point average. No modification has been made in the model presented for e-Learning styles and path analysis related to the grade point average. The goodness of fit indices of the model given in Figure 4 were examined.

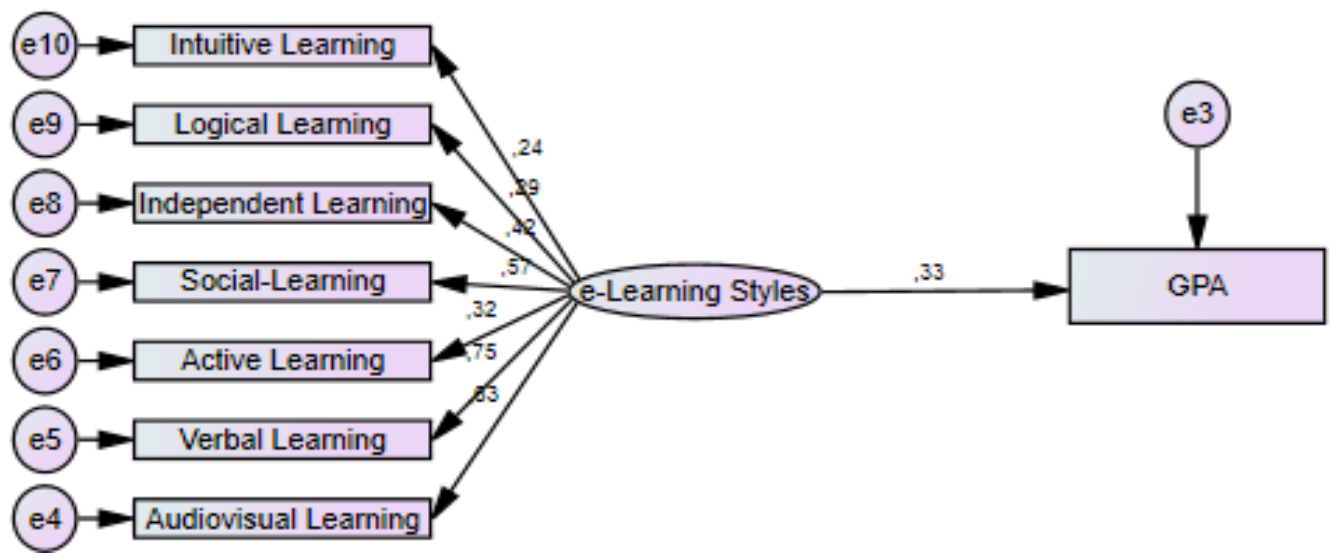

Figure 4. The relationship of e-learning style to GPA

As seen in Figure 2, it can be said that the model provides necessary criteria of goodness of fit indices $\left(X^{2}=48.63, d f=20, X^{2} / d f=2.431, A G F I=.86, G F I=.92, C F I=.81, R M S E A\right.$ $=.09$ ). The path analysis coefficients for the prediction of e-learning styles regarding the grade point average are given in Table 5. 


\section{Macrothink}

Table 5. Path analysis coefficients of e-learning styles as the predictor of the GPA

\begin{tabular}{|lr|l|l|l|l|l|}
\hline Predicted (Endogenous) & & Predictive (Exogenous) & B & S.E. & t-value & p \\
\hline OFEG & $\leftarrow$ & ELS & .33 & 4.35 & 3.30 & .000 \\
\hline
\end{tabular}

Note. ELS = E-learning Styles; GPA = Grade Point Average.

As seen in Table 5, it is seen that the e-learning style is the predictor of the grade point average $(B=.33, S E=4.35, t=3.30, p<.001)$. It was determined that the e-learning style explained $15 \%$ of the variance related to grade point average $\left(R^{2}=.15, p=.000\right)$.

The mediating role of the attitude towards distance education in the relationship between e-learning style and grade point average was examined. No modifications were made to the installed model (Figure 5). When the fit index values of the established model regarding the attitude towards distance education in the relationship between e-learning styles and the grade point average were examined, it was determined that the model had acceptable fit indices $\left(X^{2}\right.$ $\left.=75.340, d f=33, X^{2} / d f=2.283, A G F I=.85, G F I=.91, C F I=.86, R M S E A=.09\right)$.

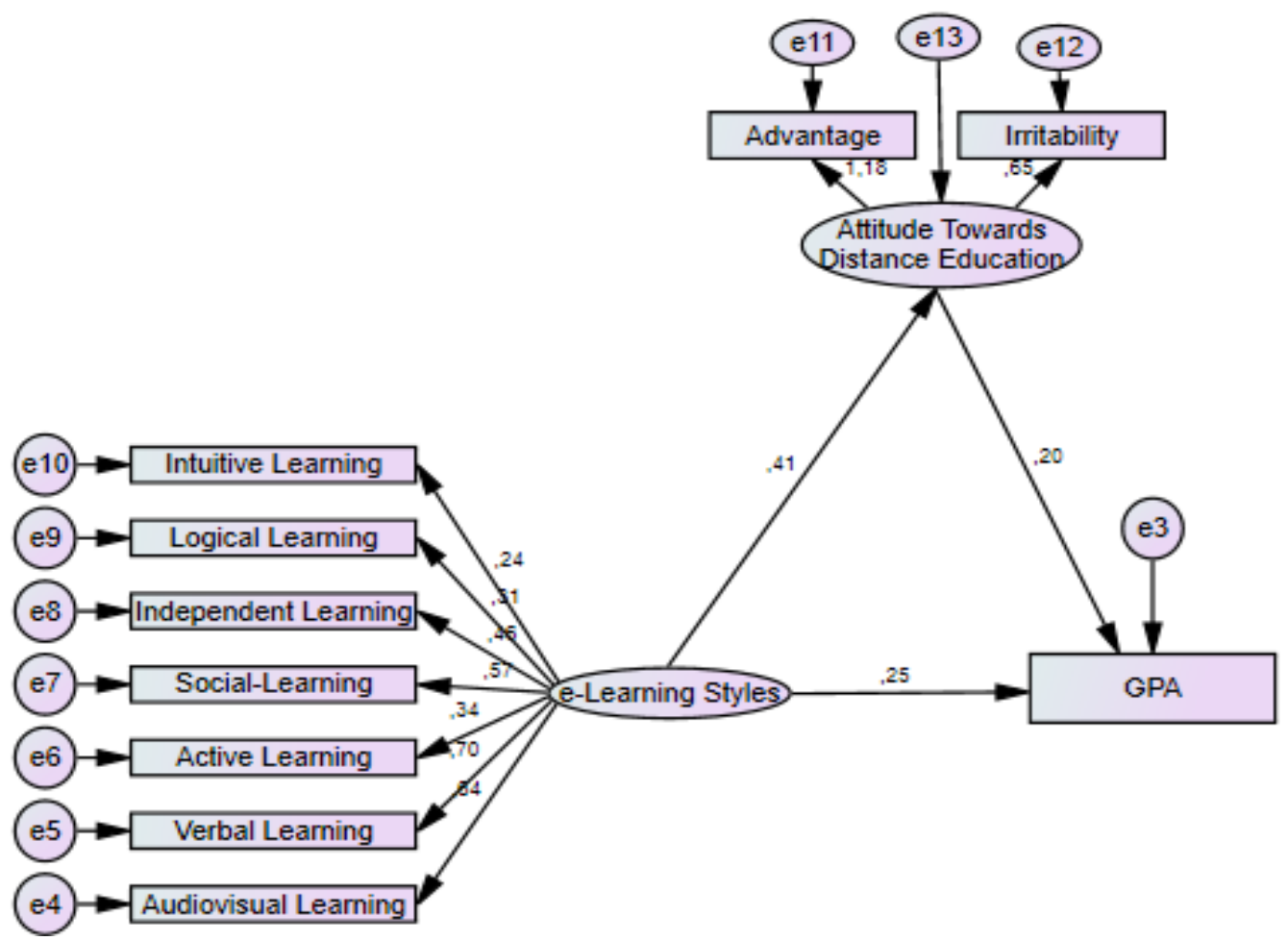

Figure 5. Mediation model showing the direct effect of e-learning style on GPA and indirect effect through attitude towards distance education

In the relationship between e-learning style and grade point average, the path analysis 
coefficients regarding the attitude towards distance education were examined. The findings obtained are given in Table 6.

Table 6. Findings related to the mediation effect of the attitude towards distance education in the relationship between e-learning styles and grade point average

\begin{tabular}{|c|c|c|c|c|c|c|}
\hline \multicolumn{2}{|c|}{ Predicted (Endogenous) } & Predictive (Exogenous) & B & S.E. & t-value & $\mathbf{p}$ \\
\hline ASDE & $\leftarrow$ & ELS & .413 & .351 & 4.721 & .000 \\
\hline GPA & $\leftarrow$ & ELS & .252 & 4.597 & 2.358 & .018 \\
\hline GPA & $\leftarrow$ & ASDE & .199 & .958 & 2.229 & .026 \\
\hline
\end{tabular}

Note. ASDE = Attitude Scale for Distance Education; ELS = E-learning Styles; GPA = Grade Point Average.

As seen in Table 6, it was determined that e-learning style predicts significantly in a positive way attitude towards distance education $(B=.41, S E=.351, t=4.721, p<.05)$ and grade point average $(B=.25, S E=4.597, t=2.358, p<.05)$. In addition, it was determined that the attitude towards distance education predicted the grade point average significantly positively $(B=.20, S E=.958, t=2.229, p<.05)$. It is seen that the attitude towards distance education and the e-Learning Style predicted $22 \%$ of the variance of the grade point average $\left(R^{2}=.222\right.$, $p<.05)$.

As can be seen, when Figure 4 and Figure 5 are compared, it was determined that the e-learning style (from .33 to .25) beta values decreased by including the attitude towards distance education to the model as a result of the path analyzes conducted to determine the mediating role of attitude towards distance education. Although beta values decreased, both variables did not lose their predictor. When the analyzes are evaluated together, It can be said that the e-learning style has a direct effect on the grade point average, but also an indirect effect through the attitude towards distance education. Accordingly, to examine the predictive effect of the variables in the model that examines the mediating role of the attitude towards distance education in the relationship between e-learning style and grade point average, the direct, indirect and total effects are reviewed and the findings obtained are given in Table 7. 
Table 7. Direct, indirect and total effects regarding structural model

\begin{tabular}{|l|l|l|l|l|l|l|}
\hline \multirow{2}{*}{ Predicted } & \multirow{2}{*}{ Predictive } & \multicolumn{3}{|c|}{ Product of Coefficients } & \multicolumn{2}{l|}{ Bootstrapping 95\% BCa Confidence Interval } \\
\cline { 3 - 7 } & & Direct & Indirect & Total & Lower & Upper \\
\hline GPA & ELS & .25 & .08 & .33 & .114 & .389 \\
\hline GPA & ASDE & .20 & - & .20 & .229 & .465 \\
\hline
\end{tabular}

Note. ASDE = Attitude Scale for Distance Education (Overall); ELS = E-learning Styles; GPA= Grade Point Average.

According to the impact values in Table 7, e-learning styles $(d=.25)$ and attitude towards distance education $(d=.20)$ were found directly and positively affect the grade point average. When the indirect effect on the grade point average was examined, it was seen that the e-learning styles $(d=.08)$ had an indirect effect on the attitude towards distance education. When the total effects of the predictive variables on the grade point average were calculated, it was determined that the e-learning styles $(d=.33)$ and the attitude towards distance education $(d=.20)$ had an effect size. Cohen (1992) interpreted the effect sizes as .10 low, .30 medium, and .50 and above strong. In this respect, it can be said that e-learning styles and attitudes towards distance education have a low level of effect considering the effect sizes on the grade point average.

Finally, in the research, the internet usage purposes of medical students were examined. Findings obtained in this direction are given in Table 8.

Table 8. Internet usage purposes of medical students

\begin{tabular}{|l|l|l|}
\hline Purpose of Internet Use & N & \% \\
\hline Social media & 72 & 48.6 \\
\hline Watching video & 25 & 16.9 \\
\hline Searching for information \& studying & 24 & 16.2 \\
\hline Playing games & 13 & 8.8 \\
\hline Listening to music & 6 & 4.1 \\
\hline Voice or video conversation & 6 & 4.1 \\
\hline Purchasing products & 2 & 1.4 \\
\hline
\end{tabular}

As seen in Table 8, when the internet usage goals of medical students are examined, social media $(48.6 \%)$, watching video $(16.9 \%)$, searching for information \& studying $(16.2 \%)$, 
playing games $(8.8 \%)$, listening to music $(4.1 \%)$, voice or video conversation $(4.1 \%)$ and purchasing products $(1.4 \%)$.

\section{Discussion}

With this research, the mediating role of attitude towards distance education in the relationship between e-learning styles of medical school students and grade point average was examined through structural equation modeling. When the findings of the research are examined, e-learning styles positively predict the grade point average. Similar findings have been found in studies by Fahy and Ally (2005), Manochehri and Young, (2006), and Offir, Bezalel and Barth (2007). Kinshuk-Graf and Liu (2009) emphasize that there should be an approach in which learning styles are taken into account in Learning Management Systems (LMS) in terms of learners' academic performance. On the other hand, Topçu (2008) concluded that awareness of the students' learning styles in online learning environments helps to increase academic performance. Accordingly, with the epidemic of COVID-19, e-learning applications have become widespread in medical education, and it can be said that considering the individual characteristics of students' learning styles and preferences in online learning environments is important for academic achievement.

In the research, it was observed that the e-learning style is the predictor of the attitude towards distance education, and the attitude towards distance education is the predictor of the grade point average. The results of the model tested in the research shows that the e-learning styles and attitude towards distance education should be taken into account on academic achievement (Carter \& Good, 1973), which is seen as the concrete output of learning in medical education conducted online. Also, it was determined in the research that e-learning styles have an indirect effect on the grade point average on attitude towards distance education. Therefore, it is considered important to consider these two variables together to increase academic achievement in online environments. Considering the e-learning styles in line with the findings of the research, taking into consideration the learning methods preferred by the students in online environments has been confirmed with the established model that it increases the attitude towards distance education and positively affects the academic achievement of the students. Similar to the findings of this research, it was found that there was a positive correlation between students' attitudes and academic achievements in e-learning environments in the research conducted by Etlioğlu and Tekin (2020). Kazazoğlu (2013) states that positive attitudes mediate students to be more successful in the learning process, while negative attitudes can cause failure, and it coincides with the findings of this research. Yenilmez, Balbağ, and Turgut (2017) stated that the attitude towards distance education and technologies is directly related to learning, and the academic achievement levels of students who do not have a positive attitude may decrease due to difficulties in getting used to the online environment. In this context, the attitudes of medical students towards distance education should be taken into account to realize effective and efficient learning in online teaching environments and to increase academic achievement. In line with the model established in this research, the importance of e-learning styles is seen in the attitude towards distance education. Therefore, it can be said that considering e-learning styles in online environments increases the attitude towards distance education and directly or 
indirectly has an effect on academic achievement.

Within the scope of the research, it is seen that the most preferred e-learning style of medical students is "logical learning". Students in the logical learning style learn best by thinking deeply. They like problem-solving activities and they want to do their work within the plan (Gülbahar \& Alper, 2014). In this regard, educational materials that students can be confronted with a problematic and complex situation or event can be used in online teaching environments to be structured for medical students. As an example of the materials that can be prepared, students can be asked to show solutions through this interactive video by showing some problematic situations in the operating environment simulated through educational videos to be developed in Shareable Content Object Reference (SCORM) type. Students can develop their skills to take responsibility and produce solutions through these materials.

When the results of the research are examined, it is seen that female students have the most "independent learning" style, while men prefer the "logical learning" style. Students in the independent learning style achieve more successful results in the application, research, and discussion activities. They are confident about learning alone. Students in the logical learning style want to do their work within the plan and learn best, in detail, and by thinking deeply (Gülbahar \& Alper, 2014). When the distribution of e-learning styles by gender is examined in the research, it is seen that gender is not a significant variable in terms of e-learning styles. Although students' dominant e-learning styles are different, it is stated that each student adopts other learning styles more or less (Dikmen, 2020). Accordingly, an online learning environment can be organized by taking into consideration the most preferred learning style in activities to be carried out according to e-learning styles in medical education. Felder and Henriques (1995) state that various combinations of different learning styles are important factors in academic achievement. As a result of this view, although learning environments are organized by considering the most preferred e-learning style of the student group in online learning environments, it shows the importance of considering other learning styles.

The finding that e-learning styles do not differ significantly according to the daily internet usage time of medical students has also been found in studies conducted by Kantoğlu (2012), Emrecik (2017), and Yetiş (2018). Kaplan and Kies (1995) state that individuals' learning styles are a feature such as congenital fingerprint or DNA (Deoxyiribo Nucleic Acid) structure and do not change easily throughout life. This can be seen as a reason why medical students' e-learning styles do not differ according to their daily internet usage time.

The results of the research are that the attitude towards distance education does not differ significantly according to gender. It is observed that similar findings have been reached in the studies conducted by Kışla (2005), Ateş and Altun (2008), Yenilmez and Ersoy (2009), Barış (2015). When the results of the research are examined, it is seen that as the duration of daily internet usage increases, attitude towards distance education also increases. Studies in the literature (Koustriava \& Papadopoulos, 2014; Özen \& Baran, 2017) support the findings of this research. Maio, Esses, Arnold, and Olson (2004) state that attitude is fed by sources such as motivation, experience, belief, and feelings. Accordingly, it is thought that as the daily 
internet usage time of medical students' increases, they have more experience in online environments and this causes to increase in their attitude towards distance education.

When the internet usage goals of medical students are examined in the research, it is seen that the most are social media, watching videos, searching for information \& studying, playing games, listening to music, voice or video conversation, studying and purchasing products. This finding is consistent with the findings of the studies conducted by Yildiz and Demir (2016), Baker and White (2010), Cheung, Chiu, and Lee (2011), Dikmen and Tuncer (2018), Almarabeh, Majdalawi, and Mohammad (2016). In the research conducted by Oğuz, Zaim, Özel, and Saka (2008) on the cognitive status of medical students on the internet, it was determined that the students mostly used social media. Few students seem to be using the internet to purchase products. This is thought to be due to the lack of financial resources of the students on their own to shop online. The students' use of the internet mostly to search for information and study supports the findings of the research.

\subsection{Limitations and Directions for Future Research}

More research is needed to evaluate the relationship between e-learning style preferences of medical students and their attitudes towards distance education and grade point average in online environments. Besides, this research focused on the attitude towards distance education with e-learning styles that are thought to affect grade point average in online environments. Future research may focus on the impact of different variables in online environments on GPA.

\subsection{Conclusions}

The research shows that medical students' preferences of e-learning style and attitudes towards distance education can be an important variable in terms of academic achievement. Taking into consideration the teaching approaches, methods, or techniques that students adopt in online learning environments can help them improve their academic performance. In addition, instructors can contribute to the realization of effective and efficient teaching by using or adapting different teaching approaches suitable for online environments. In terms of medical education, the findings of future studies will be valuable to confirm the results of this research.

\section{References}

Ağır, F., Gür, H., \& Okçu, A. (2007). Development of the attitude scale toward distance learning: Reliability and validity. Education Sciences, 3(2), 128-139.

Ahmed, H., Allaf, M., \& Elghazaly, H. (2020). COVID-19 and medical education. Correspondence, 20(7), 777-77. https://doi.org/10.1016/S1473-3099(20)30226-7

Almarabeh, T., Majdalawi, Y. K., \& Mohammad, H. (2016). Internet usage, challenges, and attitudes among university students: Case study of the University of Jordan. Journal of Software Engineering and Applications, 9(12), 577-587. https://doi.org/10.4236/jsea.2016. 912039 
Alvin, M. D., George, E., Deng, F., Warhadpande, S., \& Lee, S. I. (2020). The impact of COVID-19 on radiology trainees. Radiology, 296(2), 246-248. https://doi.org/10.1148/ radiol.2020201222

Andrew, K. H., Markku, T. N., Paolo, C. J., Damon, D., Jason, R. F., Karen, I. K., ... Anna, O. (2020). Training disrupted: Practical tips for supporting competency-based medical education during the COVID-19 pandemic. Medical Teacher, 42(7), 1-6. https://doi.org/10.1080/ 0142159X.2020.1788215

Arkonaç, S. A. (2005). Psychology: The science of mental processes. Ankara: Alpha Publications.

Atalay, N., \& Ay, Y. (2016). The relationship between academic achievement and project performance with learning styles of science teacher candidates. Electronic Turkish Studies, 11(3), 277-292. https://doi.org/10.7827/TurkishStudies.9507

Ateş, A., \& Altun, E. (2008). Investigating preservice computer teachers' attitudes towards distance learning regarding various variables. Gazi University Journal of Gazi Educational Faculty, 28(3), 125-145.

Baker, R. K., \& White, K. M. (2010). In their own words: Why teenagers don't use social networking sites. Cyberpsychology, Behavior, and Social Networking, 14(1), 395-398. https://doi.org/10.1089/cyber.2010.0016

Bandura, A. (1992). Exercise of personal agency through the self-efficacy mechanism. In R. Schwarzer (Ed.), Self-efficacy: Thought control of action (pp. 3-38). Washington, DC: Hemisphere.

Barış, M. F. (2015). Analyzing the university students' attitudes towards distance education: Namık Kemal University case study. Sakarya University Journal of Education, 5(2), 36-46. https://doi.org/10.19126/suje.38758

Beadles, N., \& Lowery, C. (2007). Self-selection into degree programs: Differences in preferred learning styles between online students and traditional students. Academy of Educational Leadership Journal, 11(2), 103-112.

Carter, V., \& Good, E. (1973). Dictionary of education (4nd ed). New York: McGraw Hill Book Company.

Chen, C. J. (2019). Differences between visual style and verbal style learners in learning English. In Management Association I (Ed.), Computer-Assisted Language Learning: Concepts, Methodologies, Tools, and Applications (pp. 1894-1908). Pennsylvania: IGI Global. https://doi.org/10.4018/978-1-5225-7663-1.ch090

Cheung, C. M. K., Chiu, P. Y., \& Lee, M. K. O. (2011). Online social networks: Why do students use Facebook? Computers in Human Behavior, 27(1), 1337-1343. https://doi.org/ 10.1016/j.chb.2010.07.028

Coffield, F., Moseley, D., Hall, E., \& Ecclestone, K. (2004). Learning styles and pedagogy in 
post-16 learning: A systematic and critical review. London: Learning and Skills Research Centre.

Cohen, J. (1992). Quantitative methods in psychology: A power primer. Psychological Bulletin, 112(1), 155-159. https://doi.org/10.1037/0033-2909.112.1.155

Dikmen, M. (2020). The effect of the instructional principles and methods course structured according to learning styles on teacher candidates' epistemological beliefs, metacognitive thinking skills, academic self-efficacy and academic achievement (Doctoral thesis, Firat University, Yükseköğretim Kurulu Başkanlığı). https://tez.yok.gov.tr/UlusalTezMerkezi/tez SorguSonucYeni.jsp

Dikmen, M., \& Çağlar, A. (2015). A study on investigation of computer and instructional technology teacher candidates' computer self-efficacy of the different variables. Istanbul Commerce University Journal of Social Sciences, 14(28), 231-249.

Dikmen, M., \& Tuncer, M. (2018). The effect of internet addiction on family relationships. Online Journal of Technology Addiction \& Cyberbullying, 5(1), 34-52.

Dikmen, S., \& Bahçeci, F. (2020). Strategies of higher education institutions for distance education in the Covid-19 pandemic process: Example of Firat University. Turkish Journal of Educational Studies, 7(2), 78-98. https://doi.org/10.33907/turkjes.721685

Elban, M. (2018). Learning styles as the predictor of academic success of the pre-service history teachers. European Journal of Educational Research, 7(3), 659-665. https://doi.org/ 10.12973/eu-jer.7.3.659

Emrecik, V., \& Özlem, O. (2019). The effects of nonverbal communication skills, which are used in video lectures, on student engagement. Eskişehir Osmangazi University Journal of Social Sciences, 20(1), 667-690. https://doi.org/10.17494/ogusbd.553853

Erdogan, Y., Bayram, S., \& Deniz, L. (2008). Factors that influence academic achievement and attitudes in web based education. Online Submission, 1(1), 31-47.

Etlioğlu, M., \& Tekin, M. (2020). The mediating role of student's curiosity and anxiety in the relationship between student attitude and academic achievement in electronic learning. Selçuk University Journal of Social Sciences Institute, 43(1), 34-48.

Fahy, P. J., \& Ally, M. (2005). Student learning style and asynchronous computer-mediated conferencing (CMC) interaction. The American Journal of Distance Education, 19(1), 5-22. https://doi.org/10.1207/s15389286ajde1901_2

Falowo, R. O. (2007). Factors impeding implementation of web-based distance learning. AACE Journal, 15(3), 315-338.

Felder, R. M., \& Henriques, E. R. (1995). Learning and teaching styles in foreign and second language education. Foreign Language Annals, 28(1), 21-31. https://doi.org/10.1111/j.19449720.1995.tb00767.x

Felder, R. M., \& Silverman, L. K. (1988). Learning and teaching styles in engineering 
education. Engineering Education, 78(7), 674-681.

Felder, R. M., \& Soloman, B. A. (2020, May 12). Index of learning styles. Retrieved from http://www4.ncsu.edu/unity/lockers/users/f/felder/public/ILSpage.html

Gülbahar, Y., \& Alper, A. (2014). Development of e-learning styles scale for electronic environments. Education and Science, 39(171), 421-435.

Hamada, A. K., Rashad, M. Z., \& Darwesh, M. G. (2011). Behavior analysis in a learning environment to identify the suitable learning style. International Journal of Computer Science \& Information Technology, 3(2), 48-59. https://doi.org/10.5121/ijcsit.2011.3204

John, A., Shahzadi, G., \& Igbal-Khan, K. (2016). Students' preferred learning styles \& academic performance. Sci. Int., 28(4), 337-341.

Junior, F. A. C., Cortat, M., Flores, C. L., Santos, F. A. M., Alves, G. C., Faiad, C., ... Silva, A. D. (2018). Evidences of validity of the Brazilian scale of learner's attitude towards distance education programs. International Journal of Information and Communication Technology Education, 14(1), 1-16. https://doi.org/10.4018/IJICTE.2018010101

Kantoğlu, B. (2012). Student satisfaction measurement in e-learning (Doctoral Dissertation, Sakarya University, Yükseköğretim Kurulu Başkanlığı). Retrieved from https://tez.yok.gov.tr/ UlusalTezMerkezi/tezSorguSonucYeni.jsp

Kaplan, E. J., \& Kies, D. A. (1995). Teaching styles and learning styles. Journal of Instructional Psychology, 22(1), 29-34.

Kazazoğlu, S. (2013). The effect of attitudes towards Turkish and English courses on academic achievement. Education and Science, 38(170), 294-304.

Kia, M. M., Aliapour, A., \& Ghaderi, E. (2009). Study of learning styles and their roles in the academic achievement of the students of Payame Noor University. Turkish Online Journal of Distance Education, 10(2), 24-37.

Kinshuk-Graf, S., \& Liu, T. C. (2009). Supporting teachers in identifying students' learning styles in learning management systems: An automatic student modelling approach. Journal of Educational Technology \& Society, 12(4), 3-14.

Kışla, T. (2005). University students' attitudes towards distance education (Master's thesis, Ege University, Yükseköğretim Kurulu Başkanlığg). Retrieved from https://tez.yok.gov.tr/ UlusalTezMerkezi/tezSorguSonucYeni.jsp

Kolb, D. A. (1976). Learning style inventory technical manual. Boston: McBer.

Konting, M. M. (1990). Educational research methods. Kuala Lumpur: Dewan Bahasa \& Pustaka.

Koustriava, E., \& Papadopoulos, K. (2014). Attitudes of individuals with visual impairments towards distance education. Universal Access in the Information Society, 13(4), 439-447. https://doi.org/10.1007/s10209-013-0331-2 
Li, R., Yin, C., Zhang, X., \& David, B. (2019). Online learning style modeling for course recommendation. In P. Srikanta \& J. Vipul (Eds.), Recent developments in intelligent computing, communication and devices (pp. 1035-1042). Singapore: Springer. https://doi.org/ 10.1007/978-981-10-8944-2_120

Maio, G. R., Esses, V. M., Arnold, K. H., \& Olson, J. M. (2004). The function-structure model of attitudes. In G. Haddock \& G. R. Maio (Eds.), Contemporary perspectives on the psychology of attitudes (pp. 11-33). USA: Psychology Press Inc.

Manochehri, N. N., \& Young, J. I. (2006). The impact of student learning styles with web-based learning or instructor-based learning on student knowledge and satisfaction. Quarterly Review of Distance Education, 7(3), 313-316.

Nassar, A. H., Zern, N. K., McIntyre, L. K., Lynge, D., Smith, C. A., Petersen, R. P., ... Wood, D. E. (2020). Emergency restructuring of a general surgery residency program during the coronavirus disease 2019 pandemic: The university of Washington experience. JAMA Surgery, 155(7), 624-627. https://doi.org/10.1001/jamasurg.2020.1219

Offir, B., Bezalel, R., \& Barth, I. (2007). Introverts, extroverts, and achievement in a distance learning environment. The American Journal of Distance Education, 21(1), 3-19. https://doi.org/10.1080/08923640701298613

Oğuz, B., Zaim, N., Özel, D., \& Saka, O. (2008). Cognitive status of medical students on the internet. Academic Information, 447-452.

Özen, E., \& Baran, H. (2020). Investigation of teachers'attitudes towards distance education in terms of different variables: The case of Eskişehir. Retrieved from https://www.researchgate.net/publication/338478807_Ogretmenlerin_Uzaktan_Egitime_Yone lik_Tutumlarinin_Farkli_Degiskenler_Acisindan_Incelenmesi_Eskisehir_Ornegi

Rose, S. (2020). Medical student education in the time of COVID-19. JAMA, 323(21), 2131-2132. https://doi.org/10.1001/jama.2020.5227

Russell, B., \& Purcell, J. (2009). Online research essentials: designing and implementing research studies (19th ed.). USA: John Wiley \& Sons.

Sherbino, J., \& Atzema, C. (2004). "SARS-Ed": Severe acute respiratory syndrome and the impact on medical education. Ann Emerg Med., 44(3), 229-231. https://doi.org/10.1016/ j.annemergmed.2004.05.021

Tabachnick, B. G., \& Fidell, L. S. (2007). Experimental designs using ANOVA. Belmont, CA: Thomson/Brooks/Cole.

Topçu, A. (2008). 'Intentional repetition' and learning style: Increasing efficient and cohesive interaction in asynchronous online discussions. British Journal of Educational Technology, 39(5), 901-919. https://doi.org/10.1111/j.1467-8535.2007.00783.x

Tuncer, M., \& Bahadır, F. (2017). Evaluation of perceptions of metacognitive thinking skills and success relations of teacher's candidates in terms of various variables. Journal of the 
Human and Social Science Researches, 6(2), 1326-1343.

Usta, I., Uysal, O., \& Okur M. R. (2016). Online learning attitude scale: Development, validity and reliability. Journal of International Social Research, 9(43), 2215-2222. https://doi.org/10.17719/jisr.20164317786

Uzuntiryaki, E., Bilgin, N., \& Geban, Ö. (2003). The Effect of Learning Styles on High School Students' Achievement and Attitudes in Chemistry (ERIC Document Reproduction Service No. ED 475 483). Paper presented at the Annual Meeting of the National Association for Research in Science Teaching, Philadelphia, PA, USA. Retrieved from https://eric.ed.gov/?id=ED475483

Whiteley, T. R. (2007). Integrating the technological resources of the online learning environment with the VAK learning-styles model to foster student learning. Paper presented at the AMAWinter Educators' Conference Proceedings.

Yenilmez, K., \& Ersoy, M. (2009). Secondary mathematics teacher candidates' opinions about distance education. Proceeding of 3rd International Computer and Instructional Technologies Symposium, Karadeniz Technical University, Trabzon, Turkey. Retrieved from https://oapub.org/edu/index.php/ejes/article/view/566

Yenilmez, K., Balbağ, M. Z., \& Turgut, M. (2017). Investigation of prospective teachers' perceptions on distance education with respect to certain variables. Erzincan University Journal of Education Faculty, 19(2), 91-107.

Yetiş, Ü. (2018). The relationship between university students' social media usage habits and e-learning styles (Master's thesis, Kahramanmaraş Sütçü İmam University, Yükseköğretim Kurulu Başkanlığı). Retrieved from https://tez.yok.gov.tr/UlusalTezMerkezi/tezSorguSonuc Yeni.jsp

Yıldız, A., \& Demir, F. M. (2016). A research on the determination of internet and social media usage objectives of the university students: Muğla Sitkı Koçman University Sample. Journal of Social Sciences and Humanities Researches, 37(1), 18-36.

\section{Copyright Disclaimer}

Copyright for this article is retained by the author(s), with first publication rights granted to the journal.

This is an open-access article distributed under the terms and conditions of the Creative Commons Attribution license (http://creativecommons.org/licenses/by/3.0/). 